\title{
The genetic predisposition to fibrocalculous pancreatic diabetes
}

\author{
P. K. Kambo ${ }^{1}$, G.A. Hitman ${ }^{1}$, V.Mohan ${ }^{2}$, A. Ramachandran ${ }^{2}$, C.Snehalatha ${ }^{2}$, S. Suresh ${ }^{3}$, K. Metcalfe ${ }^{1}$, B. K. Ryait ${ }^{1}$ \\ and M. Viswanathan ${ }^{2}$ \\ ${ }^{1}$ Medical Unit, The London Hospital, Whitechapel, London, UK, ${ }^{2}$ Diabetes Research Centre and ${ }^{3}$ Mediscan Systems, Madras, India
}

\begin{abstract}
Summary. Fibrocalculous pancreatic diabetes (previously known as tropical pancreatic diabetes) is a rare cause of diabetes confined to countries within the tropical belt. The aetiology of fibrocalculous pancreatic diabetes is thought to be environmental although the agent(s) is unknown. We have investigated a possible genetic basis of this disease by looking for restriction fragment length polymorphisms of genes implicated in the aetiology of diabetes mellitus. Seventy-six Dravidian patients with fibrocalculous pancreatic diabetes were studied, and the restriction fragment length polymorphisms obtained compared to racially matched control subjects ( $n=94$ ), patients with Type 2 (non-insulin-dependent) diabetes $(n=87)$ and Type 1 (insulin-dependent) diabetes $(n=58)$. No association of fibrocalculous pancreatic diabetes was found with restriction fragment length polymorphisms of the insulin receptor gene. Although no association of fibrocalculous pancreatic diabetes was found with polymorphism of the HLA DR $\alpha / \mathrm{DQ} \alpha / \mathrm{DX} \alpha$ genes, an association was found with the Taq 1 restriction fragment length polymorphisms of
\end{abstract}

the DQ $\beta$ gene (DQ $\beta$ T2/T6 present in $39 \%$ of patients with fibrocalculous pancreatic diabetes compared to $19 \%$ in control subjects; $p=0.01$; corrected $p$ value $=0.04$ ) which is similar to that found in Type 1 but not Type 2 diabetes. An association of fibrocalculous pancreatic diabetes was also found with the hypervariable region in the 5-prime flanking region of the insulin gene; $40 \%$ of patients possessed the class 3 allele compared to $9.5 \%$ of control subjects $p=0.0001$; corrected $p$ value $=0.0008$ ). In Type 2 diabetes, similar results were obtained with $33 \%$ subjects possessing the class 3 allele ( $p$ value compared to control subjects $=0.0005$; corrected $p$ value $=0.004$ ). This study suggests that fibrocalculous pancreatic diabetes has a genetic component in its aetiology. Furthermore, its origin might be related to an individual with part of the genetic predisposition to diabetes (Type 1 or Type 2) who additionally has evidence of chronic calcific pancreatitis.

Key words: Genetics, insulin gene, $D Q \beta$ gene, fibrocalculous pancreatic diabetes.
Malnutrition related diabetes mellitus (MRDM) is a rare cause of diabetes confined to countries in the tropical belt [1]. The World Health Organisation study group on diabetes has recommended its classification into two sub-types, namely protein deficient pancreatic diabetes (PDPD) and fibrocalculous pancreatic diabetes (FCPD) [2].

PDPD was first described by Hugh-Jones in Jamaica (previously known as J-type diabetes) and is characterised by resistance to ketosis on withdrawal of insulin, young age of onset and extreme leanness [3]. However, all these features can easily be confused with the more common forms of diabetes seen in South India [4]. In contrast, FCPD (previously known as tropical pancreatic diabetes) can be well defined, e.g. diabetes associated with chronic pancreatitis not due to a known cause of pancreatitis (for instance, alcoholism, gall stones, etc); the patient usually requires insulin for control of hyperglycaemia and is still ketosis resistant, frequently has a low body mass index (less than 18), evidence of pancreatic calculi on plain abdominal $x$-ray and often a past history of recurrent abdominal pain in childhood [4-7].

The aetiology of FCPD is not clear and is thought principally to involve environmental rather than genetic causes. The environmental agents proposed include cassava ingestion, malnutrition, and chronic viral infections; however, these factors remain controversial [8-10]. An alternative hypothesis is that chronic pancreatitis seen in the tropics produces limited B-cell destruction in an individual with a genetic predisposition to diabetes mellitus. A genetic aetiology to this disease has been suggested by Pitchumoni who observed an increased clustering of FCPD within families; however, this could equally be due to environmental factors [11]. 
We have investigated a possible genetic basis of FCPD by searching for restriction fragment length polymorphisms of genes previously studied in diabetes mellitus which might associate with FCPD. Results in FCPD were compared with those found in South Indian subjects who either had Type 1 (insulin-dependent) or Type 2 (non-insulin-dependent) diabetes to investigate a possible genetic link between these diseases and FCPD. The Type 2 diabetic population in South India provided new data in its own right, since genetic polymorphisms linked to this disease has not previously been sought in this ethnic group in which there is a high familial occurrence of diabetes [12].

\section{Subjects and methods}

\section{Diabetic patients}

All patient groups were unrelated Dravidian subjects consisting of 76 patients with FCPD, 87 with Type 2 diabetes and 58 with Type 1 diabetes. For technical reasons, not all patients were studied with all gene probes. Clinical characteristics of the patient groups are presented in Table 1.

Type 2 diabetes was defined by an insidious onset of disease, and, if on insulin, this treatment had not been initiated within five years of the diagnosis; in no subject had significant ketosis been observed.

Type 1 diabetes was defined by an acute onset of symptoms, onset of disease before the age of 35 years, proneness to ketosis and an absolute dependence on exogenously administered insulin from the time of diagnosis. In all patients with Type 1 diabetes, abdominal $x$-ray and ultrasound of the pancreas were normal.

FCPD was defined by the following criteria:

1. Diabetes mellitus as defined by the WHO Study Group.E

2. History of abdominal pain from childhood.

3. Radiological evidence of pancreatic calculi.

4. Confirmation of presence of calculi and/or pancreatic fibrosis and ductal dilation on ultrasonography.

5. The absence of known causes of chronic pancreatitis, e.g. alcoholism, gall stones, etc.

\section{Assessment of diabetic complications}

Atherosclerosis. Atherosclerosis was defined if there was evidence of ischaemic heart disease and/or peripheral vascular disease. All patients had a resting ECG taken. Ischaemic heart disease was considered to be present if there was a clear history of angina pectoris or myocardial infarction and/or the ECG demonstrated evidence of myocardial infarction or left bundle branch block. Peripheral vascular disease was deemed to be present if there was a history of intermittent claudication or if one or more peripheral pulse (dorsalis pedis or posterior tibial) was absent.

Microangiopathy. Microangiopathy was defined if there was evidence of neuropathy and/or retinopathy and/or nephropathy. Neuropathy was defined as the absence of ankle jerks bilaterally and/or a glove and stocking neuropathy. The fundi were examined by an ophthalmologist both by direct and indirect ophthalmoscopy. Diabetic retinopathy was deemed present if there was either background or proliferative retinopathy as defined by Kohner et al. [13]. Nephropathy was defined by 1 ) estimating the $24 \mathrm{~h}$ urinary protein excretion by the sulphosalicylic acid method [14] - those with values greater than $500 \mathrm{mg}$, in the absence of urinary tract infection or severe hypertension, were considered to have nephropathy or 2) a serum creatinine of greater than $133 \mu \mathrm{mol} / \mathrm{l}$.

\section{Control subjects}

Ninety-four unrelated Dravidian control subjects without a first degree family history of diabetes were recruited either from blood donors (control group $1 ; n=45$ ) or from staff and spouses of patients at the MV Hospital for diabetes (control group $2 ; n=49$ ). Detailed clinical data is presented in Table 1 for control group 2; in all subjects, random blood glucose values were below $6.7 \mathrm{mmol} / 1$. In five individuals, there was a second degree family history of Type 2 diabetes, and in the rest, there was no family history of diabetes mellitus.

\section{Methods}

DNA was extracted from $10 \mathrm{ml}$ of blood (transported to the UK at $20^{\circ} \mathrm{C}$ ) and digested with restriction endonucleases (Boehringer Mannheim, Cambridge, UK). The resulting DNA fragments were separated according to size by agarose gel electrophoresis and transferred to a nylon membrane (Gene Screen Plus, New England Nuclear, Boston, Mass, USA) by Southern blotting as previously

Table 1. Clinical characteristics of study groups

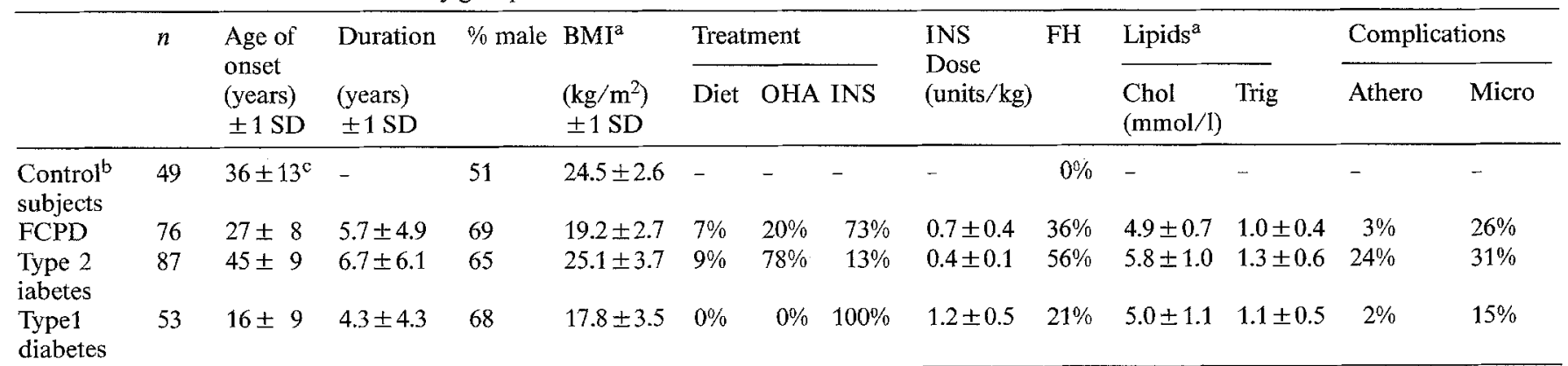

a Body mass index and lipid values were taken at first presentation of diabetes; ${ }^{\mathrm{b}}$ Control group 2: Random blood sugar $5.9 \pm 0.7 \mathrm{mmol} / \mathrm{l} ; \mathrm{HbA1}$ $7.4 \pm 0.2$ (normal range $=5-8 \%$ ). In control group $1(n=45)$ no clinical details are available apart from that all had no personal or family history of diabetes; ${ }^{\circ}$ Age at inclusion of study

Key: $\mathrm{FH}=$ first degree family history of Type 2 diabetes; Chol=cholesterol; Trig = triglyceride; $\mathrm{n}=$ number; $\mathrm{BMI}=$ body mass index; Athero = atherosclerosis (ischaemic heart disease/peripheral vascular disease); micro = microvascular disease (retinopathy/neuropathy/nephropathy); $\mathrm{OHA}=$ oral hypoglycaemic agents; $\mathrm{INS}=$ insulin 
described [15]. The appropriate probe was labelled with ${ }^{32} \mathrm{P}$ labelled cytosine triphosphate and hybridised to the filter according to the manufacturer's protocol (New England Research Products, Boston, Mass, USA). Autoradiography was carried out at $-70^{\circ}$ on Kodak XAR5 film. Gene related sequences were sized by comparison with Hind III digested $\lambda$ phage DNA and internal standards.

The following probes and enzymes were used:

Insulin receptor. This is located on chromosome 17 , and is a $4.1 \mathrm{~kb}$ cDNA fragment containing the coding region of the $\alpha$ and $\beta$ chain of the insulin receptor [16]. The probe was excised from the plasmid vector using Eco RI restriction endonuclease. Patient DNA was digested with restriction enzyme Rsa I.

Insulin gene (pHins 310). This is located on chromosome 11 and encodes the hypervariable region flanking the insulin gene [17]. The $0.87 \mathrm{~kb}$ fragment was excised from the plasmid vector using Bam $\mathrm{HI}$ restriction endonuclease. Patient DNA was digested with the restriction enzyme Pvu II.

HLA-D region probes: $D R \alpha, D Q \alpha$ and $D Q \beta$. All are located on the short arm of chromosome 6. DR $\alpha$ is a Pst I cDNA fragment, $0.3-0.5 \mathrm{~kb}$ in length [18]. DQ $\alpha$ is a Pst I $2.0 \mathrm{~kb}$ genomic fragment and also identifies with the DX $\alpha$ gene [19]. DQ $\beta$ is a Ava I cDNA fragment of pDRB1, $0.6 \mathrm{~kb}$ in length [20]. Patient DNA was digested with $\mathrm{Bgl} \mathrm{II}(\mathrm{DR} \alpha)$ and Taq $1(\mathrm{DQ} \alpha / \mathrm{DQ} \beta)$.

Table 2. Insulin receptor polymorphism in fibrocalculous pancreatic diabetes, Type 2 diabetes and control subjects of Dravidian origin

\begin{tabular}{|c|c|c|c|c|}
\hline & \multicolumn{4}{|c|}{ Insulin receptor polymorphisms (Rsa I) } \\
\hline & & $7.4 / 7.4$ & $7.4 / 6.3$ & $6.3 / 6.3$ \\
\hline Control subjects & $n=85$ & $35 \%$ & $47 \%$ & $18 \%$ \\
\hline $\begin{array}{l}\text { Fibrocalculous } \\
\text { pancreatic diabetes }\end{array}$ & $n=71$ & $21 \%$ & $51 \%$ & $28 \%^{\mathrm{a}}$ \\
\hline Type 2 diabetes & $n=85$ & $26 \%$ & $50.5 \%$ & $23.5 \%$ \\
\hline
\end{tabular}

$3 \times 2$ Chi square analysis; disease compared to control subjects

${ }^{a} p=$ not significant (NS)

\section{Statistical analysis}

Results were analysed by Chi square using a Yates correction for small numbers when appropriate [21]. Where significant associations were found the $p$ values were multiplied by the number of comparisons (pc) made within each individual experiment, (e.g. subject group - in all cases 4 - multiplied by the number of independent markers within each experiment), and relative risk and 95\% confidence limits were calculated by the method of Woolf [22]. Analysis of variance was used for comparison of mean values between study groups [23].

\section{Results}

\section{Insulin receptor restriction fragment length polymorphisms}

The Rsa I polymorphism was characterised by the presence of 7.4 and $6.3 \mathrm{~kb}$ bands. No differences were found between control subjects and patients with either FCPD or Type 2 diabetes (Table 2).

\section{Insulin gene RFLPS}

Using Pvu II restriction endonuclease, and the hypervariable region probe, two alleles of the 5' flanking region designated Class 1 and Class 3 were detected [17]. An individual could be homozygous for Class 1 allele $(1,1)$, homozygous for Class 3 allele or heterozygous, i. e. Class $1 /$ Class 3 . No differences in insulin genotype distribution were observed between control group 1

Table 3a. Insulin gene distribution and allelic frequency in fibrocalculous pancreatic diabetes, Type 2 diabetes, Type 1 diabetes and control subjects of Dravidian origin

\begin{tabular}{|c|c|c|c|c|c|c|c|c|}
\hline & & \multicolumn{2}{|c|}{ Genotype frequency } & $\begin{array}{l}3 \times 2 \\
\chi^{2}\end{array}$ & $p$ & $p c^{\mathrm{a}}$ & $\begin{array}{l}\text { Relative } \\
\text { risk }\end{array}$ & $\begin{array}{l}95 \% \text { Confidence } \\
\text { limits }\end{array}$ \\
\hline Control subjects & $n=83$ & $90.5 \%$ & $9.5 \% \%^{b}$ & & & & & \\
\hline Type 2 diabetes & $n=78$ & $67 \%$ & $33 \%{ }^{b}$ & 12.2 & 0.0005 & 0.004 & 4.7 & $2.0-11.2$ \\
\hline Type 1 diabetes & $n=53$ & $79 \%$ & $21 \%{ }^{\mathrm{b}}$ & 2.5 & NS & NS & 2.5 & $0.9-6.6$ \\
\hline
\end{tabular}

$1=$ Class 1 allele; $3=$ Class 3 allele. ${ }^{a}$ pc: $p$ value multiplied by the number of comparisons made, e.g. (subjects 4 , markers 2 ; correction factor 8 );

b $1 \%$ of control subjects, $5 \%$ of fibrocalculous pancreatic diabetes, $4 \%$ of Type 2 diabetes and $2 \%$ of Type 1 diabetes subjects were homozygous for the Class 3 allele

Table $3 \mathbf{b}$. Distribution of certain clinical details according to insulin genotype in the diabetic patients

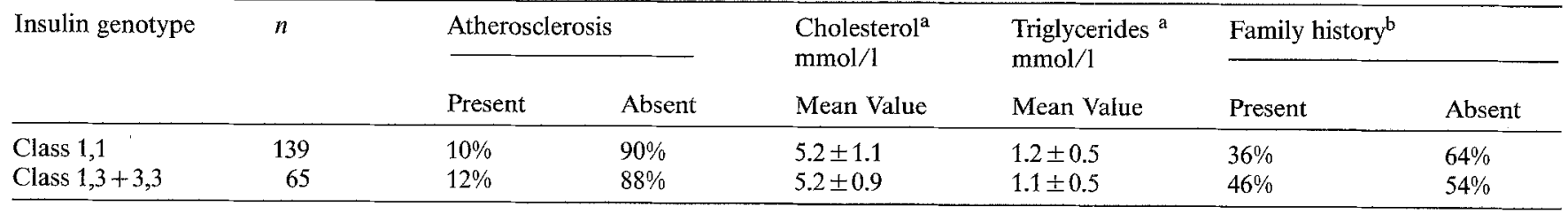

All comparisons between $1,1 \mathrm{v}(1,3+3,3)$ not significant. ${ }^{\text {a }}$ excludes control subjects. No differences of insulin genotypes within FCPD or Type 1 or Type 2 diabetes were found for the presence of atherosclerosis or the mean values of cholesterol or triglyceride; ${ }^{b}$ in Type 2 diabetes $73 \%$ $(19 / 26)$ who possessed the Class 3 allele compared to $45 \%(23 / 51)$ who were homozygous for the Class 1 allele had a first degree family history of Type 2 diabetes $\left(\chi^{2}=4.4 ; p=0.04 ; p c=\mathrm{NS}\right)$. No differences were observed within FCPD nor Type 1 diabetes 
Table 4. DQ $\alpha$ allelic frequencies in fibrocalculous pancreatic diabetes, Type 2 diabetes, Type 1 diabetes and control subjects of Dravidian origin

\begin{tabular}{lllllll}
\hline & \multicolumn{5}{c}{ DQ 0 RFLPs (Taq 1) } \\
\cline { 2 - 7 } & & $6.8 \mathrm{~kb}$ & $6.2 \mathrm{~kb}$ & $5.5 \mathrm{~kb}$ & $4.6 \mathrm{~kb}$ & $2.6 \mathrm{~kb}$ \\
\hline Control subjects & $n=91^{\mathrm{a}}$ & $20 \%$ & $15.5 \%$ & $37 \%$ & $11 \%$ & $16.5 \%$ \\
Fibrocalculous & $n=63$ & $20.5 \%$ & $19 \%$ & $32.5 \%$ & $8 \%$ & $20 \%{ }^{\mathrm{b}}$ \\
pancreatic diabetes & & & & & & \\
Type 2 diabetes & $n=41$ & $23 \%$ & $8 \%$ & $35 \%$ & $13 \%$ & $20 \%^{\mathrm{c}}$ \\
Type 1 diabetes & $n=57^{\mathrm{a}}$ & $\mathbf{1 1 . 5 \%}$ & $10.5 \%$ & $32 \%$ & $32 \%$ & $14 \%^{\mathrm{d}}$ \\
\hline
\end{tabular}

${ }^{\text {a }}$ Includes some subjects in whom results have been published [24] $5 \times 2$ Chi square analysis of disease compared to control subjects; ${ }^{\mathrm{b}} \chi^{2}=2.2 ; \quad p=\mathrm{NS} ;{ }^{\mathrm{c}} \chi^{2}=2.8 ; \quad p=\mathrm{NS} ;{ }^{\mathrm{d}} \chi^{2}=21.1 ; \quad p=0.0003$; $p \mathrm{c}=0.006$. $\mathrm{pc}=p$ value corrected for number of comparisons made (subjects 4 , alleles 5 , correction factor 20 )

Table 5. DX $\alpha$ allelic frequency in fibrocalculous pancreatic diabetes, Type 2 diabetes, Type 1 diabetes and Dravidian control subjects

\begin{tabular}{llll}
\hline & & \multicolumn{2}{c}{ DX $\alpha$ allelic frequency } \\
\cline { 3 - 4 } & & $2.1 \mathrm{~kb}$ & $1.9 \mathrm{~kb}$ \\
\hline Control subjects & $n=91^{\mathrm{a}}$ & $28 \%$ & $72 \%$ \\
Fibrocalculous & $n=64$ & $27 \%$ & $73 \%$ \\
pancreatic diabetes & & $34 \%$ & $66 \%$ \\
Type 2 diabetes & $n=41$ & $30 \%$ & $70 \%$ \\
Type 1 diabetes & $n=53^{\mathrm{a}}$ & & \\
\hline
\end{tabular}

${ }^{a}$ Includes some subjects as previously published [24]

Table 6. DQ $\beta$ RFLPs in fibrocalculous pancreatic diabetes, Type 2 diabetes, Type 1 diabets and control subjects of Dravidian origin

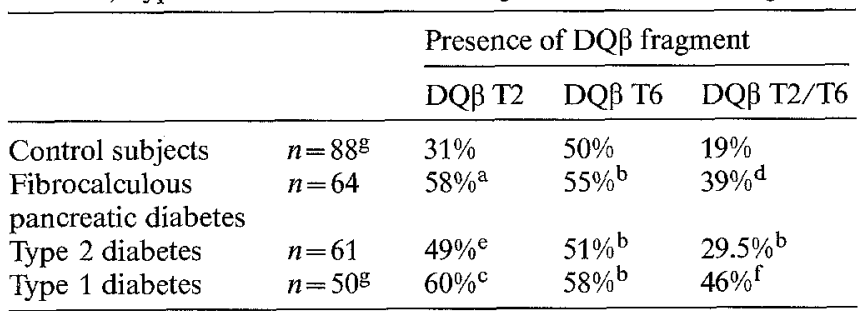

Abbreviations: T2 and T6 refer to Taq 1 fragments sized 2 and $6 \mathrm{~kb}$ detected with a cDNA DQ $\beta$ probe [25]. Differences between disease compared to control subjects $\left(2 \times 2\right.$ Chi square). ${ }^{\mathrm{a}} \chi^{2}=10.1$; $p=0.0015 ; p \mathrm{c}=0.012 ;{ }^{\mathrm{b}} p=\mathrm{NS} ;{ }^{\mathrm{c}} \chi^{2}=10.1 ; p=0.001 ; p \mathrm{c}=0.008$

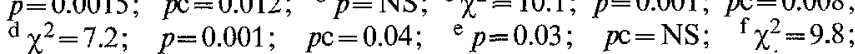
$p=0.002 ; p c=0.008 . \quad p c=p$ value corrected by number of

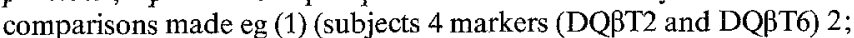
correction factor 8); (2) (subjects 4 and DQßT2/T6); correction factor 4) ${ }^{g}$ Includes some subjects previously published [24]

$(95 \%: 1,1)$ and control group $2(88 \%: 1,1)$; therefore, results were pooled for further analysis. Detailed results are shown in Table $3 \mathrm{a}$. A high frequency of subjects possessing the Class 3 allele was seen in FCPD and Type 2 diabetes compared to control subjects (control subjects $9.5 \%$ and FCPD $40 \%, p=0.0008$; Type 2 diabetes $33 \%, p c=0.004$; Type 1 diabetes $21 \%$, $p c=$ NS). The frequency of the Class 3 allele was not different (either in FCPD or Type 1 or Type 2 diabetes alone or when results are pooled) according to the presence or absence of atherosclerosis, nor was it asso- ciated with higher levels of lipids compared to those subjects homozygous for the Class 1 allele (Table $3 b$ ). Those Type 2 diabetic subjects who had a first degree family history of diabetes were more likely to also possess the Class 3 allele ( $73 \%$ compared to $45 \%$ in those with a family history of Type 2 diabetes who were homozygous for the Class 1 allele; $p=0.04, p c=\mathrm{NS}$ ). This was not the case in FCPD or Type 1 diabetes.

\section{$D Q \alpha / D X \alpha R F L P S$}

Using Taq 1 enzyme, five DQ $\alpha$ gene fragments were identified. These were sized $6.8,6.2,5.5,4.6$ and $2.6 \mathrm{~kb}$ [15]. The DX $\alpha$ fragments sized 2.1 and $1.9 \mathrm{~kb}$ were also detected using the same probe [15]. Allelic frequencies for the DQ $\alpha$ polymorphism (Table 4) shows no association with either FCPD or Type 2 diabetic subjects. The $\mathrm{DQ} \alpha 4.6 \mathrm{~kb}$ fragment showed an association with Type 1 diabetes ( $32 \%$ vs $11 \%$ in control subjects) as previously documented [24]. No difference was found in allelic frequency of 2.1 and $1.9 \mathrm{~kb}$ DX $\alpha$ alleles (Table 5). Only 41 Type 2 diabetic subjects were studied for $\mathrm{DQ} \alpha / \mathrm{DX} \alpha$ RFLPs, as there were clearly no differences in distribution of alleles in Type 2 diabetic subjects compared to control subjects.

\section{$D Q \beta$ RFLPS}

Using Taq 1, we had previously identified two non-allelic fragments sized $2 \mathrm{~kb}$ (T2) and $6 \mathrm{~kb}$ (T6) which, when co-inherited in British Caucasoid subjects, closely associate with HLA DR4 $[25,26]$. DQ $\beta$ T2 was increased in FCPD and Type 1 diabetes compared to control subjects (Table 6: control subjects 31\% compared to FCPD $58 \% ; p c=0.01$ and Type 1 diabetes $60 \%$; $p c=0.008)$. Although DQ $\beta$ T2 was increased in Type 2 diabetes $(49 \% ; p=0.03)$, this was not significantly different from control subjects when corrected for the number of comparisons made. DQ $\beta$ T6 was found in $39 \%$ of patients with FCPD compared to $46 \%$ of Type 1 diabetic subjects, $29.5 \%$ of Type 2 diabetic subjects and $19 \%$ of control subjects (FCPD compared to control subjects $p \mathrm{c}=0.04$ )

\section{DRo RFLPS}

Using Bgl II, three allelic fragments were identified sized 4.5, 4.2 and $3.8 \mathrm{~kb}[15]$. No association of these alleles were seen with FCPD and Type 2 diabetes. Only 45 subjects with Type 2 diabetes were studied as there was clearly no difference in DR $\alpha$ alleles between patients and control subjects. The decreased prevalence of the $3.8 \mathrm{~kb}$ allele in Type 1 diabetes was as previously noted [24] (Table 7). 


\section{Discussion}

This study suggests that FCPD may result from a genetic predisposition to diabetes in patients who have evidence of chronic pancreatitis.

The comparison of clinical data between FCPD, Type 1 and Type 2 diabetes highlights different clinical aspects of these three diseases (Table 1). Body mass index $\left(\mathrm{kg} / \mathrm{m}^{2}\right)$ in FCPD $(19.2 \pm 2.7)$ was very similar to that in Type 1 diabetes $(17.8 \pm 3.5)$; whereas, it was different to that in Type 2 diabetes $(25.1 \pm 3.7)$. Mean age of onset in subjects with FCPD ( $27 \pm 8$ years) was between the age of onset in subjects with Type 1 (16 \pm 9 years) and Type 2 ( $45 \pm 9$ years) diabetes. Patients with FCPD and Type 1 diabetes had lower cholesterol and triglyceride values compared to subjects with Type 2 diabetes. Lastly, the majority of patients with FCPD required insulin for control of diabetes; although it is interesting to note that they required on average less units per kilogram than subjects with Type 1 diabetes and therefore, were not insulin resistant as is sometimes described.

Several loci have been postulated to be involved in the pathogenesis of Type 2 diabetes, in particular, the insulin receptor and insulin gene. The present insulin receptor data supports findings in other racial populations that there is no association of this locus with Type 2 diabetes [27-29]. The finding of the Class 3 allele of the insulin gene associating with Type 2 diabetes (relative risk $=4.7 ; 95 \%$ confidence limits of 2.0-11.2) supports similar studies in European Caucasoids [30, 31] (UK and Denmark), Japanese subjects [32, 33] and American Caucasoids in San Francisco [34]. However, other population studies of American Caucasoids in Los Angeles [17], Pima Indians [35], Punjabi Sikhs [27] and Naurian Indians [36] failed to find the same associations; indeed in one a Class 1 allele association was noted [17]. One explanation is that the primary association is not with Type 2 diabetes but with an associated disorder, e.g. hypertriglyceridaemia [37] or atherosclerosis [38]. However, data for this has also proved controversial [39]. In this study, no association was seen of atherosclerosis (ischaemic heart disease and/or peripheral vascular disease) or hyperlipidaemia with the Class 3 allele in all disease groups (Table 3 B). In one Japanese study, those Type 2 diabetic subjects with a family history of diabetes had an increased frequency of the Class 3 allele [32]; although a trend was observed in this study $73 \%$ versus $45 \%$ of Type 2 diabetic subjects who were homozygous class 1 , it was not statistically significant when corrected for the number of comparisons made, and the same association was not seen in FCPD or Type 1 diabetes. An alternative hypothesis is genetic heterogeneity, e. g. linkage in some racial groups between the Class 3 allele and Type 2 diabetes which is not present in other groups. This may be analogous to the association of a Hpa I RFLP of the $\beta$ globin gene in sickle cell anaemia which is found in West but not East
Table 7. DR $\alpha$ allelic frequency in FCPD, Type 2 diabetes, Type 1 diabetes and control subjects

\begin{tabular}{lllll}
\hline & \multicolumn{4}{l}{$\mathrm{DR} \alpha$ allelic frequency } \\
\cline { 2 - 5 } & Subjects & $4.5 \mathrm{~kb}$ & $4.2 \mathrm{~kb}$ & $3.8 \mathrm{~kb}$ \\
\hline Control subjects & $n=94^{\mathrm{c}}$ & $68.5 \%$ & $8.5 \%$ & $23 \%$ \\
Fibrocalculous & $n=76$ & $73.5 \%$ & $5 \%$ & $20.5 \% \%^{\mathrm{a}}$ \\
pancreatic diabetes & & & & \\
Type 2 diabetes & $n=45$ & $72 \%$ & $8 \%$ & $20 \% \%^{\mathrm{a}}$ \\
Type 1 diabetes & $n=58^{\mathrm{c}}$ & $93 \%$ & $1 \%$ & $6 \% 0^{\mathrm{b}}$ \\
\hline
\end{tabular}

$3 \times 2$ Chi square analysis of disease compared to control subjects. ${ }^{\mathrm{a}} p=\mathrm{NS} ;{ }^{b} \chi^{2}=25.4 ; p<0.00001, p c=0.0001 . p c=p$ value corrected for comparison made, e.g. (subjects 4 , alleles 3 ; correction factor 12$) ;{ }^{c}$ Includes some subjects previously published [24]

Africans [40]. Family studies have failed to prove linkage of a subtype of Type 2 diabetes, maturity onset diabetesin the young, (MODY) with the insulin gene [41-43]. However, these families do not represent the common form of disease analysed in most population studies. One study has suggested linkage of hyperproinsulinaemia with the insulin gene haplotypes [44]. Finally it is likely that heterogeneity within Type 2 diabetes exists, further complicating the picture.

Genes within the human MHC are not thought to be involved in the aetiology of Type 2 diabetes. However, in a previous study of Dravidian subjects [45] although no association of Type 2 diabetes was found with HLAA, HLA-B, properdin factor B, second component of complement nor glyoxylase, an association was seen of the fourth component of complement (in particular, a decrease of C4B1 and an increase in C4B2). Furthermore, a weak association of HLA-Bw61 with South African Indians has recently been noted [46]. In our study, although there was an increase of DQ $\beta$ T 2 in Type 2 diabetic subjects $(49 \%)$ compared to control subjects $(31 \% ; p=0.03)$, this was not statistically significant when corrected for the number of comparisons made in this experiment.

A consistent finding in both American and European Caucasoid subjects has been an association of the Class 1 allele of the insulin gene and Type 1 diabetes; the meaning of this association is unclear $[17,47]$. This association is not seen in this study or Japanese or American black subjects with Type 1 diabetes $[32,33$, 48]. These observations, therefore, rule out a direct relationship of the hypervariable region of the insulin gene in the predisposition to Type 1 diabetes but are compatible with a gene predisposing to Type 1 diabetes which is linked in some ethnic groups with the hypervariable region.

In our previous study of Type 1 diabetic Dravidian subjects, associations of diesease were noted with $\mathrm{DQ} \alpha$ 4.6 and DQ $\beta$ T2 and DQ $\beta$ T2/T6 [24]. No association of FCPD is seen with DQ $\alpha 4.6$ (Table 4) in contrast to the associations with $D Q \beta$ polymorphism (Table 6). This $\mathrm{DQ} \beta$ association might therefore indicate a common genetic predisposition to both FCPD and Type 1 diabetes in Dravidian subjects. It is interesting to specu- 
late that because there is no $\mathrm{DQ} \alpha$ or $\mathrm{DR} \alpha$ association seen in FCPD in contrast to Type 1 diabetes (Tables 4 and 7) this might account for part of the phenotypic difference between the two diseases.

Particularly interesting was that $40 \%$ of patients with FCPD compared to $9.5 \%$ of control subjects possessed the Class 3 allele of the insulin gene locus (relative risk 6.2; 95\% confidence limits 2.6-14.7). Thus, in Dravidian subjects the Class 3 allele of the insulin gene associates with FCPD and Type 2 diabetes. This indicates the possibility of Type 2 diabetes sharing a genetic factor with FCPD. Alternatively, the association of the Class 3 allele with FCPD might represent the high background population prevalence of Type 2 diabetes amongst South Indians [49]. Some overlap of FCPD patients was seen who had both the Class 3 allele and DQ $\beta$ T2 $(13 / 64 ; 20 \%)$ compared to $1 / 80(1 \%)$ of the control subjects $\left(\chi^{2}=12.6 ; p=0.0004\right) .72 .5 \%$ of FCPD patients had either or both the insulin and HLA DQ $\beta$ markers compared to $39 \%$ of control subjects $\left(\chi^{2}=14.2 ; p=0.0002\right)$.

In conclusion, this study suggests that fibrocalculous pancreatic diabetes arises in an individual who has part of the prexisting genetic susceptibility to either Type 1 or Type 2 diabetes and evidence of chronic pancreatitis. No conclusion can be reached as to the origin of the pancreatitis which might involve either or both genetic and environmental factors. Family studies are now in progress to ascertain whether segregation of the insulin gene and HLA markers can be found in pedigrees with a member who has FCPD.

Acknowledgements. Part of this work was supported by the British Diabetic Association. Gene probes were kindly donated by A. Ullrich (Genentech, San Francisco, Calif., USA; insulin receptor), G. IBell (Chiron Corporation, Emeryville, Calif., USA; insulin gene), P. A. Petterson (University of Uppsala, Uppsala, Sweden; HLA-DR $\alpha$ and HLA-DQB) and J.Trowsdale (Imperial Cancer Research Fund, London, UK; HLA-DQ $\alpha$ ).

\section{References}

1. Abu-Bakare A, Taylor R, Gill GV, Alberti KGMM (1986) Tropical or malnutrition-related diabetes: a real syndrome? Lancet I: $1135-1138$

2. WHO study group report on diabetes mellitus (1985) WHO Technical Report Series 727

3. Hugh-Jones P (1955) Diabetes in Jamaica. Lancet II: 891

4. Mohan V, Ramachandran A, Viswanathan M (1985) Tropical diabetes. In: Alberti KGMM, Krall LP (eds) The Diabetes annual 1. Elsevier, Amsterdam New York, pp 82-92

5. Viswanathan M (1980) Pancreatic diabetes in India: an overview. In: Podolsky S, Viswanathan M (eds) Secondary diabetes: the spectrum of the diabetic syndromes. Raven Press, New York, pp $105-116$

6. Mohan V, Mohan R, Susheela L, Snehalatha C, Bharani G, Mahajan VK, Viswanathan M, Kohner EM (1985) Tropical pancreatic diabetes in S India: heterogeneity in clinical and biochemical profile. Diabetologia 28: 229-232

7. Mohan V, Snehalatha C, Jayashree R, Ramachandran A, Viswanathan M (1983) Pancreatic beta cell function in tropical pancreatic diabetes. Metabolism 32: 1091-1092
8. McMillan DE, Geevarghese PJ (1979) Dietary cyanide and tropical malnutrition diabetes. Diabetes Care 2: 202-208

9. Teuscher T, Baillod P, Rosman JB, Teuscher A (1987) Absence of diabetes in a rural West African population with a high carbohydrate/cassava diet. Lancet I: 765-768

10. Shenoy KT, Shanmugham J, Balaknshnan V (1986) Viral and mycoplasma pneumoniae antibodies in chronic pancreatitis of tropics. Indian J Med Res 84: 22-26

11. Pitchumoni CS (1970) Familial pancreatitis. In: Pai KN, Suman CR, Varghese R (eds) Pancreatic diabetes. Geoprinters, Trivandrum, pp 46-48

12. Viswanathan $M$, Mohan V, Snehalatha C, Ramachandran A (1985) High prevalence of Type 2 (non-insulin-dependent) diabetes among the offspring of conjugal Type 2 diabetic parents in India. Diabetologia 28: $907-910$

13. Kohner EM, McLeod D, Matshall J (1982) Diabetic eye disease. In: Keen H, Jarret RJ (eds) Complications of diabetes, 2nd edn. Edward Arnold, London, pp 19-108

14. Varley H, Gowenlock $A H$; Bell M (1980) Practical clinical biochemistry. Heinmann, London, pp 600-601

15. Hitman GA, Niven MJ, Festenstein H, Cassell PG, Awad J, Walker-Smith J, Leonard JN, Fry L, Ciclitira P, Kumar P, Sachs JA (1987) HLA Class II alpha chain gene polymorphisms in patients with insulin dependent diabetes mellitus, dermatitis herpetiformis, and coeliac disease. J Clin Invest 79: 609-615

16. Ullrich A, Bell JR, Chen EY, Herrera R, Pettuzzelli LM, Dutt TS, Gray A, Cousens L, Liao YC, Tsubokawa M (1985) Human insulin receptor and its relationship to the tyrosine kinase family of oncogenes. Nature 313: 756-761

17. Bell GI, Horita S, Karam JA (1984) A polymorphic locus near the human insulin gene is associated with insulin dependent diabetes mellitus. Diabetes 33: 176-186

18. Larhammer D, Gustafsson K, Claesson L, Bill P, Wiman K, Schenning L, Sundelin J, Widmark E, Peterson PA, Rask L (1982) Alpha chain of HLA-DR transplantation antigen is a member of the same protein superfamily as the immunoglobulins. Cell 30 : 153-161

19. Spielman RS, Lee J, Bodmer WF, Bodmer JG, Trowsdale J (1984) Six HLA-D region $\alpha$ chain genes on human chromosome 6: polymorphisms and associations of DC $\alpha$-related sequences with DR types. Proc Natl Acad Sci USA 81: 3461-3465

20. Larhammer D, Schenning L, Gastafsson K, Wiman K, Claesson L, Rask L, Peterson PA (1982) Complete amino acid sequence of an HLA DR antigen like $\beta$ chain as predicted from the nucleotide sequence: similarities with immunoglobulins and HLA-A -B and $-C$ antigens. Proc Natl Acad Sci 79: 3687-3691

21. Norusis MJ (1986) SPSS/PC + for the IBM PC/XT/AT. Pubs SPSS, B93-B107

22. Emery AEH (1976) Methodology and medical genetics. Churchill Livingstone, Edinburgh, pp 98-108

23. Norusis MJ (1986) SPSS/PC+ for the IBM PC/XT/AT. Pubs SPSS, B165-B175

24. Hitman GA, Karir PK, Sachs JA, Ramachandran A, Snehalatha C, Viswanathan M, Mohan V (1988) HLA-D region RFLPs indicate that susceptibility to insulin-dependent diabetes in South India is located in the HLA-DQ region. Diab Med 5: 57-60

25. Festenstein H, Awad J, Hitman GA, Cutbush S, Groves AV, Cassell P, Ollier W, Sachs JA (1986) New HLA DNA polymorphisms associated with autoimmune diseases. Nature 322:64-67

26. Sachs JA, Cassell PG, Festenstein H, Awad J, Hitman GA (1987) $D Q \beta$ restriction fragment length polymorphism and its relationship to insulin dependent diabetes mellitus. Dis Markers 5: 199-206

27. Hitman GA, Karir PK, Mohan V, Rao PV, Kohner EM, Levy JC, Mather $H$ (1987) A genetic analysis of Type 2 (non-insulin-dependent) diabetes mellitus in Punjabi Sikhs and British Caucasoid patients. Diab Med 4: 526-530

28. Takeda J, Seino $Y$, Yoshimass $Y$, Fukumoto $G$, Koh G, Kuzuya H, Imura H, Seino S (1986) Restriction fragment length polymorphism of the human insulin receptor gene in Japanese: 
its possible usefulness as a genetic marker. Diabetologia 29: 667-669

29. Elbein SC, Borecki I, Corsetti L, Fajans SS, Hansen AT, Nerup J, Province M, Permutt MA (1987) Linkage analysis of the human insulin receptor gene and maturity onset diabetes of young. Diabetologia 30: 641-647

30. Owerbach D, Nerup J (1982) Restriction fragment length polymorphism of the insulin gene in diabetes mellitus. Diabetes 31 : $275-277$

31. Hitman GA, Jowett NI, Williams LG, Humphries S, Winter RM, Galton DJ (1984) Polymorphisms in the $5^{\prime}$ flanking region of the insulin gene and non-insulin-dependent diabetes. Clin Sci 66: 383-388

32. Nomura M, Iwama N, Mukai M, Saito Y, Kawamori R, Shichiri M, Kamada T (1986) High frequency of Class 3 allele in the human insulin gene in Japanese Type 2 (non-insulin-dependent) diabetic patients with a family history of diabetes. Diabetologia 29: $402-404$

33. Awata T, Shibasaki Y, Hirai H, Okabe T, Kanazawa Y, Takaku F (1986) Restriction fragment length polymorphism of the insulin gene in Japanese diabetic and non-diabetic subjects. Diabetologia 28: 911-913

34. Rotwein PS, Chirgwin J, Province M, Knowler WC, Pettitt DJ, Cordell B, Goodwin HM, Permutt MA (1983) Polymorphism in the 5' flanking region of the human insulin gene: a genetic marker for non-insulin-dependent diabetes mellitus. N Engl J Med 308: $65-71$

35. Knowler WC, Pettitt DJ, Vasquez B, Rotwein PS, Andreone TL, Permutt MA (1984) Polymorphism in the $5^{\prime}$ flanking region of the human insulin gene. Relationships with non-insulin dependent diabetes mellitus, glucose and insulin concentration and diabetes treatment in the Pima Indians. $J$ Clin Invest 74: 2129-2135

36. Serjeantson SW, Owerbach D, Zimmet P, Nerup J, Thoma K (1983) Genetics of diabetes in Nauru: effects of foreign admixture, HLA antigens and the insulin gene linked polymorphism. Diabetologia 25:13-17

37. Jowett NI, Williams LG, Hitman GA, Galton DJ (1984) Diabetic hypertriglyceridaemia and related 5 ' flanking polymorphism of the insulin gene. $\mathrm{Br}$ Med $\mathbf{J}$ 288: 96-99

38. Mandrup-Poulsen T, Owerbach D, Mortensen SA, Johansen K, Meinertz-Sorensen H, Nerup J (1984) DNA sequences flanking the insulin gene on chromosome 11 confer risk of atherosclerosis. Lancet I: $253-255$

39. Rees A, Stocks J, Williams LG, Caplin JL, Jowett NI, Camm AJ, Galton DJ (1985) DNA polymorphisms of the Apo CIII and insulin genes and atherosclerosis. Atherosclerosis: $58: 296-275$
40. Kan YW, Dozy AM (1980) Evolution of the haemoglobin S and C genes in world populations. Science 209: 388-391

41. Bell JI, Wainscoat JS, Old JM, Chlouverakis C, Keen H, Turner RC, Weatherall DJ (1983) Maturity onset diabetes of the young is not linked to the insulin gene. Br Med J 286: 590-592

42. Andreone T, Fajan S, Rotwein P, Skolnick M, Permutt MA (1985) Insulin gene analysis in a family with maturity-onset diabetes of the young. Diabetes 34: 108-114

43. Owerbach D, Thomsen B, Johansen K, Lamm LU, Nerup J (1983) DNA insertion sequences near the insulin gene are not associated with maturity-onset diabetes of young people. Diabetologia $25: 18-20$

44. Elbein SC, Gruppuso P, Schwartz R, Skolnick M, Permutt MA (1985) Hyperproinsulinemia in a family with a proposed defect in conversion is linked to the insulin gene. Diabetes 34: 821-824

45. Kirk RL, Ranford PR, Serjeantson SW, Thompson AR, Munirathman Chetty SM, Lilly John, Mohan V, Ramachandran A, Snehalatha C, Viswanathan M (1985) HLA complement C2, C4, properdin, factor B and glyoxalase types in South Indian diabetics. Diab Res Clin Pract 1: 41-47

46. Omar MAF, Hammond MG, Motala AA, Seedat MD (1988) HLA Class I and II antigens in South African indians with NIDDM. Diabetes 37: 796-799

47. Hitman GA, Tarn AC, Winter RM, Drummond V, Williams LG, Jowett NI, Bottazzo GF, Galton DJ (1985) Type 1 (insulin-dependent) diabetes and a highly variable locus close to the insulin gene on chromosome 11. Diabetologia 28: 218-222

48. Elbein S, Rotwein P, Permutt MA, Bell GI, Sanz N, Karam JH (1985) Lack of association of the polymorphic locus in the $5^{\prime}$ flanking region of the human insulin gene and diabetes in American blacks. Diabetes 34: 433-439

49. Ramachandran A, Jali MV, Mohan V, Snehalatha C, Viswanathan M (1988) High prevalence of diabetes in semi-urban populations in South India. Br Med J 297: 587-590

Received: 23 June 1988

and in revised form: 10 November 1988

\author{
Dr. G.A. Hitman \\ Medical Unit \\ The London Hospital \\ Whitechapel \\ London E1 1BB \\ U. K.
}

